\title{
Investigation of Suitable Structure of Ionic Liquids for the Synthesis of Phthalocyanines
}

\author{
Satoshi Kitaoka ${ }^{1 *}$, Kaoru Nobuoka ${ }^{2}$ and Shintaroh Izawa ${ }^{1}$ \\ 1 Department of Biotechnology and Chemistry, Faculty of Engineering, Kindai University, Umenobe 1, Takaya, \\ Higashihiroshima 739-2116. \\ 2 Division of applied Chemistry, Faculty of Science and Technology, Oita University, 700 Dannoharu, Oita 870-1192. \\ * Corresponding author: Fax: 81-82-434-7000, and/or e-mail: kitaoka@hiro.kindai.ac.jp
}

\begin{abstract}
The preparation of phthalocyanines are difficult because of their poor reactivity of reactants. In order to improve the reactivity, safety, and green technology in the preparation of the phthalocyanine (4-tBuPcH 2$)$, several types of ionic liquids were applied as reaction medium. In the case of using $\left[\mathrm{C}_{2}-\mathrm{OHm}\right.$ im] $[\mathrm{Br}]$ as a reaction media, 4- $\mathrm{BBuPCH}_{2}$ was obtained in the highest yield (38\%). These results suggested that the hydroxy groups, anion species, and stability of cations of ionic liquids are important to synthesis of $4-\mathrm{HBPcH}_{2}$. In addition, $\left[\mathrm{C}_{2}-\mathrm{OHm} 2 \mathrm{im}\right][\mathrm{Br}]$ was reused without any loss of its catalytic activity.
\end{abstract}

Key words: ionic liquids, phthalocyanine, green chemistry, porphyrin

\section{INTRODUCTION}

The phthalocyanine and its derivatives are widely used in various fields, such as dyes and pigments, ${ }^{1}$ chemical sensors, ${ }^{2}$ photosensitizer for photodynamic therapy, ${ }^{3}$ non-linear optical materials, ${ }^{4}$ liquid crystals, ${ }^{5}$ and catalysts ${ }^{6}$ due to their high thermal stability and attractive chemical properties. There are two general approaches to the synthesis of some phthalocyanines and its derivatives. One is a condensation of phthalonitriles by refluxing with metal alkoxide or DBU in alcohol, and the other is fusion methods with phthalic anhydrides or its derivatives. ${ }^{7}$ These methods often requires high reaction temperature $\left(100-300{ }^{\circ} \mathrm{C}\right)$, prolonged reaction time, strong basic condition and troublesome workup procedures. In order to achieve favorable reaction conditions such as more gentle, safe and lower energy, it is expected the development of the green phthalocyanine synthesis.

Ionic liquids (ILs) could be suitable and environmentally safer replacements for the volatile, toxic, and flammable organic solvents. In addition, ILs can easily dissolve many compounds involving some porphyrins. In fact, there are various reports about using ILs as reaction media and catalysis. ${ }^{8-9}$ We have studied the utilization of ILs to prepare porphyrins. ${ }^{10-13}$ The synthetic method of phthalocyanine is greatly different from other porphyrin derivatives, though phthalocyanines are one of the porphyrin derivatives. Base is necessary for the preparations the phthalocyanines, while acid is necessary for the preparations of other porphyrins. Tetrabutylammonium bromide ${ }^{14,15}$ and $1,1,3,3-N, N, N$, $N$ '-tetramethylguanidium bromide ${ }^{16}$ have been used as ILs for phthalocyanines and metallophthalocyanines synthesis. In addition, hydroxylated ammonium based ILs have been used for synthesis of phthalocyanines ${ }^{17}$ and metallophthalocyanines. ${ }^{18}$ In particular, the methods utilizing hydroxylated ammonium based $\operatorname{ILs}^{17,18}$ are worthy of attention, because hydroxylated ammonium based ILs act as basic catalyst by combining with DBU. While the effects of ILs structure on the preparation of

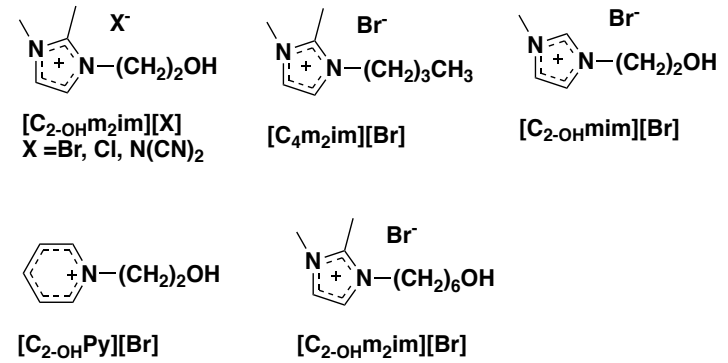

Fig.1 Structures of Ionic Liquids used in this study

metallophthalocyanines have been studied, the effect on the preparation of free base phthalocyanines has not been clarified. Because the preparation of free base phthalocyanines is not metal template synthesis, its reactivity is lower than that of metallophthalocyanines. In addition, the reactivity of the substituted phthalonitriles used in the preparation of phthalocyanines having substituents which improve their solubility in various solvents are lower than that of unsubstituted phthalonitrile. In this paper, we focused on the 4,4',4",4"'tetra-tert-butylphthalocyanine $\left(4-\mathrm{tBuPcH}_{2}\right)$, because 4-tBuPcH $\mathrm{H}_{2}$ can be dissolved in the many kinds of solvents and be useful in many fields. The purpose of this study was investigation of the suitable ILs structure for the phthalocyanine preparation, and to improve the yield of the phthalocyanines. We focused our attention on the following points of ILs structures. (1) hydroxy group, (2) $\mathrm{C}_{2}-\mathrm{H}$ of imidazolium, (3) cation skeletons, (4) anion species, (5) spacer length between imidazolium ring and hydroxy group (Fig.1).

\section{EXPERIMENTAL}

All reagents were reagent grade and were used as received from Aldrich without further purification. All the ILs were dried in vacuo (under $0.1 \mathrm{mbar}$ ) at $60^{\circ} \mathrm{C}$ for 1 day prior to use. TLC analyses was performed on $0.25 \mathrm{~mm}$ 
Silica gel Merck 60 F254 plates. NMR spectra were recorded on a $400 \mathrm{MHz}$ spectrometer. Chemical shifts $(\delta$ $\mathrm{ppm})$ in DMSO- $d_{6}$ were reported downfield from TMS (0 ppm) for ${ }^{1} \mathrm{H}$ NMR.

\subsection{Preparations of ILs}

Preparation of 1-(2'-hydroxyethyl)-2,3-dimethylimidazolium bromide, $\left[\mathrm{C}_{2}-\mathrm{OH} \underline{\mathrm{m}}_{2} \underline{\mathrm{im}}\right][\mathrm{Br}]$ (1)

A mixture of 1,2-dimethylimidazole $(5.0 \mathrm{~g}, 52 \mathrm{mmol})$ and 2-bromoethanol $(4.4 \mathrm{~mL}, 62 \mathrm{mmol})$ in acetonitrile $(20 \mathrm{~mL})$ was refluxed with stirring 7 hours. After removal of the solvent, the residue was diluted with water $(50 \mathrm{~mL})$ and washed with chloroform ( 3 X $50 \mathrm{~mL})$. A spatula tip of activated charcoal was added to the aqueous phase and stirred 1 hour. The activated charcoal was removed by filtration, and the solvent was removed under reduced pressure. The residue was further dried in vacuo (under 0.1 mbar) at $60{ }^{\circ} \mathrm{C}$ for 24 hours, which gave a white solid (yield: $10.2 \mathrm{~g}, 46 \mathrm{mmol}, 88 \%) .{ }^{1} \mathrm{H}$ NMR(400 MHz, DMSO- $d_{6}$-TMS $): \delta=7.61(\mathrm{~d}, 2 \mathrm{H}, \mathrm{C} 4-\mathrm{H}+\mathrm{C} 5-\mathrm{H}), 5.08(\mathrm{t}$, $1 \mathrm{H}, \mathrm{OH}), 4.18\left(\mathrm{t}, 2 \mathrm{H}, \mathrm{NCH}_{2} \mathrm{CH}_{2} \mathrm{OH}\right), 3.75\left(\mathrm{~s}, 3 \mathrm{H}, \mathrm{N}-\mathrm{CH}_{3}\right)$ 3.75-3.66 (m, 2H, $\left.\mathrm{NCH}_{2} \mathrm{CH}_{2} \mathrm{OH}\right), 2.58\left(\mathrm{~s}, 3 \mathrm{H}, \mathrm{C} 2-\mathrm{CH}_{3}\right)$. ESI-MS $\left(\mathrm{CH}_{3} \mathrm{OH}\right)$, positive ion $141\left[\mathrm{C}_{2-\mathrm{OH}} \mathrm{m}_{2} \mathrm{im}\right]$, negative ion $81[\mathrm{Br}]$.

\section{Preparation of 1-butyl-2,3-dimethylimidazolium bromide, $\left[\mathrm{C}_{4} \mathrm{~m}_{2} \mathrm{im}\right][\mathrm{Br}]$ (2)}

A mixture of 1,2-dimethylimidazole $(10.0 \mathrm{~g}, 104 \mathrm{mmol})$ and 1-bromobutane $(13.0 \mathrm{~mL}, 125 \mathrm{mmol})$ in acetonitrile $(50 \mathrm{~mL})$ was refluxed with stirring 4 hours. After removal of the solvent, the residue was diluted with water $(50 \mathrm{~mL})$ and washed with chloroform $(3 \times 50 \mathrm{~mL})$. A spatula tip of activated charcoal was added to the aqueous phase and stirred one hour. The activated charcoal was removed by filtration, and the solvent was removed under reduced pressure. The residue was further dried in vacuo (under $0.1 \mathrm{mbar}$ ) at $60^{\circ} \mathrm{C}$ for 24 hours, which gave a white solid (yield: $24.1 \mathrm{~g}, 104 \mathrm{mmol}, 99 \%) .{ }^{1} \mathrm{H}$ NMR(400 MHz, DMSO- $d_{6}$-TMS) $: \delta=7.64(\mathrm{~s}, 1 \mathrm{H}, \mathrm{C} 4-\mathrm{H}), 7.61(\mathrm{~s}, 1 \mathrm{H}$, $\mathrm{C} 5-\mathrm{H}), 4.11\left(\mathrm{t}, 2 \mathrm{H}, \mathrm{N}-\mathrm{CH}_{2}\right), 3.73\left(\mathrm{~s}, 3 \mathrm{H}, \mathrm{N}-\mathrm{CH}_{3}\right), 2.57(2$, $\left.3 \mathrm{H}, \mathrm{C} 2-\mathrm{CH}_{3}\right), 1.71\left(\mathrm{~m}, 2 \mathrm{H}, \mathrm{N}-\mathrm{CH}_{2} \mathrm{CH}_{2} \mathrm{CH}_{2} \mathrm{CH}_{3}\right), 1.32$ (m, $2 \mathrm{H}, \mathrm{N}-\mathrm{CH}_{2} \mathrm{CH}_{2} \mathrm{CH}_{2} \mathrm{CH}_{3}$ ), $0.91\left(\mathrm{t}, 3 \mathrm{H}, \mathrm{N}-\mathrm{CH}_{2} \mathrm{CH}_{2} \mathrm{CH}_{2} \mathrm{CH}_{3}\right.$ ). ESI-MS $\left(\mathrm{CH}_{3} \mathrm{OH}\right)$, positive ion $153\left[\mathrm{C}_{4} \mathrm{~m}_{2} \mathrm{im}\right]$, negative ion $81[\mathrm{Br}]$.

Preparation of 1-butyl-2,3-dimethylimidazolium chloride, $\left[\mathrm{C}_{4} \underline{\mathrm{m}}_{2} \mathrm{im}\right][\mathrm{Cl}]$ (3)

A mixture of 1,2-dimethylimidazole $(5.0 \mathrm{~g}, 52 \mathrm{mmol})$ and 2-chloroethanol $(4.2 \mathrm{~mL}, 62 \mathrm{mmol})$ in acetonitrile $(20 \mathrm{~mL})$ was refluxed with stirring 42 hours. After removal of the solvent, the residue was diluted with water $(50 \mathrm{~mL})$ and washed with chloroform $(3 \times 50 \mathrm{~mL})$. A spatula tip of activated charcoal was added to the aqueous phase and stirred one hour. The activated charcoal was removed by filtration, and the solvent was removed under reduced pressure. The residue was further dried in vacuo (under $0.1 \mathrm{mbar}$ ) at $60{ }^{\circ} \mathrm{C}$ for 24 hours, which gave a white solid (yield: $7.04 \mathrm{~g}, 40 \mathrm{mmol}, 78 \%) . \quad{ }^{1} \mathrm{H} \mathrm{NMR}(400 \mathrm{MHz}$, DMSO- $d_{6}$-TMS $): \delta=7.64(\mathrm{~d}, 2 \mathrm{H}, \mathrm{C} 4-\mathrm{H}+\mathrm{C} 5-\mathrm{H}), 5.25(\mathrm{t}$, $1 \mathrm{H}, \mathrm{OH}), 4.18\left(\mathrm{t}, 2 \mathrm{H}, \mathrm{NCH}_{2} \mathrm{CH}_{2} \mathrm{OH}\right), 3.75\left(\mathrm{~s}, 3 \mathrm{H}, \mathrm{N}-\mathrm{CH}_{3}\right)$ 3.70-3.68 (m, $\left.2 \mathrm{H}, \mathrm{NCH}_{2} \mathrm{CH}_{2} \mathrm{OH}\right), 2.58\left(\mathrm{~s}, 3 \mathrm{H}, \mathrm{C} 2-\mathrm{CH}_{3}\right)$. ESI-MS $\left(\mathrm{CH}_{3} \mathrm{OH}\right)$, positive ion $141\left[\mathrm{C}_{2-\mathrm{OH}} \mathrm{m}_{2} \mathrm{im}\right]$, negative ion $35[\mathrm{Br}]$.
Preparation of 1-(2'-hydroxyethyl)-2,3-dimethylimidazolium dicyanamide, $\left[\mathrm{C}_{2}-\mathrm{OH} \underline{\mathrm{m}}_{2} \mathrm{im}\right]\left[\mathbf{N}(\mathbf{C N})_{2}\right]$ (4)

To a solution of sodium dicyanamide $(4.5 \mathrm{~g}, 51 \mathrm{mmol})$ in water $(30 \mathrm{~mL})$ was added the silver nitrate $(8.58 \mathrm{~g}, 51$ $\mathrm{mmol})$, and the reaction mixture was stirred for 2 hours at room temperature. The precipitate (silver dicyanamide) was collected by filtration. To a solution of $\left[\mathrm{C}_{2-\mathrm{OH}} \mathrm{m}_{2} \mathrm{im}\right][\mathrm{Br}](10.1 \mathrm{~g}, 46 \mathrm{mmol})$ in water $(30 \mathrm{~mL})$ was added the silver dicyanamide, and the reaction mixture was stirred overnight at room temperature. The precipitate was removed by filtration. A spatula tip of activated charcoal was added and the mixture was stirred 1 hour at room temperature. The activated charcoal was removed by filtration, and the solvent was removed under reduced pressure. The residue was further dried in vacuo (under $0.1 \mathrm{mbar}$ ) at $60{ }^{\circ} \mathrm{C}$ for 24 hours, which gave a pale yellow liquid (yield: $7.1 \mathrm{~g}, 34 \mathrm{mmol}, 86 \%$ ). ${ }^{1} \mathrm{H}$ $\operatorname{NMR}\left(400 \mathrm{MHz}, \mathrm{DMSO}-d_{6}\right.$-TMS) $: \delta=8.22(\mathrm{~s}, 1 \mathrm{H}, \mathrm{C} 4-\mathrm{H})$, $7.51(\mathrm{~s}, 1 \mathrm{H}, \mathrm{C} 5-\mathrm{H}), 5.00(\mathrm{t}, 1 \mathrm{H}, \mathrm{OH}), 4.09(\mathrm{t}, 2 \mathrm{H}$, $\left.\mathrm{NCH}_{2} \mathrm{CH}_{2} \mathrm{OH}\right), \quad 3.67\left(\mathrm{~s}, \quad 3 \mathrm{H}, \quad \mathrm{N}-\mathrm{CH}_{3}\right) 3.60(\mathrm{~m}, \quad 2 \mathrm{H}$, $\left.\mathrm{NCH}_{2} \mathrm{CH}_{2} \mathrm{OH}\right), 2.45\left(\mathrm{~s}, 3 \mathrm{H}, \mathrm{C} 2-\mathrm{CH}_{3}\right)$. ESI-MS $\left(\mathrm{CH}_{3} \mathrm{OH}\right)$, positive ion $141\left[\mathrm{C}_{2-\mathrm{OH}} \mathrm{m}_{2} \mathrm{im}\right]$, negative ion $66\left[\mathrm{~N}(\mathrm{CN})_{2}\right]$.

\section{Preparation of 1-(2'-hydroxyethyl)-3-methylimida-} zolium bromide, $\left[\mathrm{C}_{2}\right.$-OH $\left.\mathrm{mim}\right][\mathrm{Br}]$ (5)

A mixture of 1-methylimidazole $(5.0 \mathrm{~mL}, 63 \mathrm{mmol})$ and 2-bromoethanol $(5.3 \mathrm{~mL}, 75 \mathrm{mmol})$ in acetonitrile $(20 \mathrm{~mL})$ was refluxed with stirring 4 hours. After removal of the solvent, the residue was diluted with water $(50 \mathrm{~mL})$ and washed with chloroform ( 3 X $50 \mathrm{~mL})$. A spatula tip of activated charcoal was added to the aqueous phase and stirred 1 hour. The activated charcoal was removed by filtration, and the solvent was removed under reduced pressure. The residue was further dried in vacuo (under 0.1 mbar) at $60{ }^{\circ} \mathrm{C}$ for 24 hours, which gave a white solid (yield: $11.3 \mathrm{~g}, 55 \mathrm{mmol}, 88 \%) .{ }^{1} \mathrm{H}$ NMR(400 MHz, DMSO- $d_{6}$-TMS $): \delta=9.08(\mathrm{~s}, 1 \mathrm{H}, \mathrm{C} 2-\mathrm{H}), 7.72(\mathrm{~s}, 1 \mathrm{H}$, $\mathrm{C} 4-\mathrm{H}), 7.69(\mathrm{~s}, 1 \mathrm{H}, \mathrm{C} 5-\mathrm{H}), 5.18(\mathrm{t}, 1 \mathrm{H}, \mathrm{OH}), 4.21(\mathrm{t}, 2 \mathrm{H}$, $\left.\mathrm{NCH}_{2} \mathrm{CH}_{2} \mathrm{OH}\right), 3.85\left(\mathrm{~s}, 3 \mathrm{H}, \mathrm{N}-\mathrm{CH}_{3}\right) 3.72-3.68(\mathrm{~m}, 2 \mathrm{H}$, $\left.\mathrm{NCH}_{2} \mathrm{CH}_{2} \mathrm{OH}\right)$. ESI-MS $\left(\mathrm{CH}_{3} \mathrm{OH}\right)$, positive ion 127

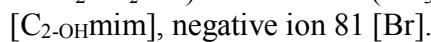

\section{Preparation of N-(2'-hydroxyethyl)-pyridinium} bromide, $\left[\mathrm{C}_{2-\mathrm{OH}} \mathrm{Py}\right][\mathrm{Br}](6)$

A mixture of pyridine $(5.0 \mathrm{~mL}, 60 \mathrm{mmol})$ and 2-bromoethanol $(5.0 \mathrm{~mL}, 70 \mathrm{mmol})$ in acetonitrile $(20 \mathrm{~mL})$ was refluxed with stirring 19 hours. After removal of the solvent, the residue was diluted with water $(50 \mathrm{~mL})$ and washed with chloroform ( 3 X $50 \mathrm{~mL})$. A spatula tip of activated charcoal was added to the aqueous phase and stirred one hour. The activated charcoal was removed by filtration, and the solvent was removed under reduced pressure. The residue was further dried in vacuo (under $0.1 \mathrm{mbar}$ ) at $60{ }^{\circ} \mathrm{C}$ for 24 hours, which gave a white solid (yield: $11.1 \mathrm{~g}, 54 \mathrm{mmol}, 91 \%) .{ }^{1} \mathrm{H} \mathrm{NMR}(400 \mathrm{MHz}$, DMSO- $d_{6}$-TMS $): \delta=9.01(\mathrm{~d}, 2 \mathrm{H}, o-\mathrm{H}), 8.62(\mathrm{t}, 1 \mathrm{H}, p-\mathrm{H})$, $8.16(\mathrm{t}, 2 \mathrm{H}, m-\mathrm{H}), 5.25(\mathrm{br}, 1 \mathrm{H}, \quad \mathrm{OH}) 4.66(\mathrm{t}, 2 \mathrm{H}$, $\left.\mathrm{NCH}_{2} \mathrm{CH}_{2} \mathrm{OH}\right), 3.85\left(\mathrm{t}, 2 \mathrm{H}, \quad \mathrm{NCH}_{2} \mathrm{CH}_{2} \mathrm{OH}\right)$. ESI-MS $\left(\mathrm{CH}_{3} \mathrm{OH}\right)$, positive ion $124\left[\mathrm{C}_{2-\mathrm{OH}} \mathrm{Py}\right]$, negative ion 81 [Br].

Preparation of 1-(6'-hydroxyhexyl)-2,3-dimethylimidazolium bromide, $\left[\mathrm{C}_{6-\mathrm{OH}} \mathrm{m}_{2} \mathrm{im}\right][\mathrm{Br}](7)$

A mixture of 1,2-dimethylimidazole $(5.0 \mathrm{~g}, 52 \mathrm{mmol})$ and 
6-bromohexanol $(8.1 \mathrm{~mL}, 62 \mathrm{mmol})$ in acetonitrile $(50$ $\mathrm{mL}$ ) was refluxed with stirring 18 hours. After removal of the solvent, the residue was diluted with water $(50 \mathrm{~mL})$ and washed with chloroform $(3 \times 50 \mathrm{~mL})$. A spatula tip of activated charcoal was added to the aqueous phase and stirred one hour. The activated charcoal was removed by filtration, and the solvent was removed under reduced pressure. The residue was further dried in vacuo (under $0.1 \mathrm{mbar}$ ) at $60{ }^{\circ} \mathrm{C}$ for 24 hours, which gave a pale yellow liquid (yield: $12.2 \mathrm{~g}, 44 \mathrm{mmol}, 85 \%) .{ }^{1} \mathrm{H}$ NMR(400 MHz, DMSO- $d_{6}$-TMS) $: \delta=7.60(\mathrm{~d}, 2 \mathrm{H}, \mathrm{C} 4-\mathrm{H}), 7.55(\mathrm{~d}$, $2 \mathrm{H}, \mathrm{C} 5-\mathrm{H}), 4.31(\mathrm{~s}, 1 \mathrm{H}, \mathrm{OH}), 4.06(\mathrm{t}, 2 \mathrm{H}, \mathrm{NCH}), 3.34(\mathrm{~m}$, $\left.2 \mathrm{H}, \mathrm{N}-\mathrm{CH}_{2} \mathrm{CH}_{2} \mathrm{CH}_{2}\left(\mathrm{CH}_{2}\right)_{2} \mathrm{CH}_{2} \mathrm{OH}\right), 2.53\left(\mathrm{~s}, 3 \mathrm{H}, \mathrm{C} 2-\mathrm{CH}_{3}\right)$, $1.68\left(\mathrm{~m}, 2 \mathrm{H}, \mathrm{N}-\mathrm{CH}_{2} \mathrm{CH}_{2} \mathrm{CH}_{2}\left(\mathrm{CH}_{2}\right)_{2} \mathrm{CH}_{2} \mathrm{OH}\right), 1.38(\mathrm{~m}, 2 \mathrm{H}$, $\left.\mathrm{N}-\mathrm{CH}_{2} \mathrm{CH}_{2} \mathrm{CH}_{2}\left(\mathrm{CH}_{2}\right)_{2} \mathrm{CH}_{2} \mathrm{OH}\right), 1.25\left(\mathrm{~m}, 4 \mathrm{H}, \mathrm{N}-\mathrm{CH}_{2} \mathrm{CH}_{2}\right.$ $\left.\mathrm{CH}_{2}\left(\mathrm{CH}_{2}\right)_{2} \mathrm{CH}_{2} \mathrm{OH}\right)$. ESI-MS $\left(\mathrm{CH}_{3} \mathrm{OH}\right)$, positive ion 197 $\left[\mathrm{C}_{6-\mathrm{OH}} \mathrm{m}_{2} \mathrm{im}\right]$, negative ion $81[\mathrm{Br}]$.

\subsection{Preparations of phthalocyanine in ILs}

\section{Preparation of 4,4,4",4"'-tetra-tert-butylphthalocyani} $\underline{\text { ne, 4-tBuPcH }} 2$ in $\left[\mathrm{C}_{2-\mathrm{OH}} \underline{\mathrm{m}}_{2}\right.$ im] $[\mathrm{Br}]$

$2 \mathrm{~mL}$ of $\left[\mathrm{C}_{2-\mathrm{OH}} \mathrm{m}_{2} \mathrm{im}\right][\mathrm{Br}]$ was melted at $80{ }^{\circ} \mathrm{C}$ in the test tube. 4-tert-butylphtalonitrile $(360 \mathrm{mg}, 1.95 \mathrm{mmol})$ and DBU $(0.304 \mathrm{~mL}, 2.03 \mathrm{mmol})$ were added in to $\left[\mathrm{C}_{2-\mathrm{OH}} \mathrm{m}_{2} \mathrm{im}\right][\mathrm{Br}]$. After stirring for 5 hours at $120^{\circ} \mathrm{C}$, the reaction mixture was dissolved in the chloroform $(100$ $\mathrm{mL})$ and distilled water $(100 \mathrm{~mL})$. After the water phase including $\left[\mathrm{C}_{2-\mathrm{OH}} \mathrm{m}_{2} \mathrm{im}\right][\mathrm{Br}]$ was separated, the chloroform phase including 4-tBuPcH ${ }_{2}$ was washed with distilled water $(3 \times 50 \mathrm{~mL})$. The chloroform phase was dried over anhydrous sodium sulfate and the chloroform was removed under reduced pressure. The residue was dissolved in dichloromethane and chromatographed on silica gel with dichloromethane elution to get deep blue powder (90 mg, $0.12 \mathrm{mmol}, 38 \%$ ). UV-vis $\left(\mathrm{CHCl}_{3}\right)$ : $\lambda$ $\max (\mathrm{nm}) 701,664,644,602,341$.

Preparations of 4-tBuPcH $\mathrm{H}_{2}$ in other ILs were conducted on the same procedure in $\left[\mathrm{C}_{2-\mathrm{OH}} \mathrm{m}_{2} \mathrm{im}\right][\mathrm{Br}]$.

\section{RESULTS AND DISCUSSION}

First, 4-tBuPcH${ }_{2}$ was prepared in ILs, $\left[\mathrm{C}_{2-\mathrm{OH}} \mathrm{m}_{2} \mathrm{im}\right][\mathrm{Br}]$ (Table 1). $\quad\left[\mathrm{C}_{2-\mathrm{OH}} \mathrm{m}_{2} \mathrm{im}\right][\mathrm{Br}]$ was heated until liquid state $\left(80{ }^{\circ} \mathrm{C}\right)$, because $\left[\mathrm{C}_{2-\mathrm{OH}} \mathrm{m}_{2} \mathrm{im}\right][\mathrm{Br}]$ is solid at room temperature. 4-tert-butylphthalonitrile $(0.9 \mathrm{M})$ and $\mathrm{DBU}$ $(1.0 \mathrm{M})$ was added in the liquid $\left[\mathrm{C}_{2-\mathrm{OH}} \mathrm{m}_{2} \mathrm{im}\right][\mathrm{Br}]$. After reaction mixture was heated at $120{ }^{\circ} \mathrm{C}$ for 6 hours, $4-\mathrm{tBuPcH}_{2}$ was obtained in $38 \%$ yield. In contrast, 4- $\mathrm{tBuPcH}_{2}$ was obtained in $4.4 \%$ yield by refluxing with ethanol as a molecular solvent. Although reaction temperature is different, the yield of $4-\mathrm{tBuPcH}_{2}$ was higher in ILs than in molecular solvent. These results suggested that the phthalocyanine synthesis maybe accelerated in ILs. Therefore, we investigated the key structure of ILs in the phthalocyanine synthesis by 4 - $\mathrm{tBuPcH} \mathrm{H}_{2}$ preparation in various ILs.

The influence of hydroxy group was investigated by using $\left[\mathrm{C}_{4} \mathrm{~m}_{2} \mathrm{im}\right][\mathrm{Br}]$. In $\left[\mathrm{C}_{2-\mathrm{OH}} \mathrm{m}_{2} \mathrm{im}\right][\mathrm{Br}]$ with hydroxy group, 4- $\mathrm{tBuPcH}_{2}$ was obtained in $38 \%$ yield (Table 2, Entry 1), whereas in $\left[\mathrm{C}_{4} \mathrm{~m}_{2} \mathrm{im}\right][\mathrm{Br}]$ without hydroxy group, only $4 \%$ of $4-\mathrm{tBuPcH}_{2}$ was obtained (Table 2, Entry 2). Thus, the plausible mechanism of $4-\mathrm{tBuPcH}_{2}$ synthesis in ILs is the same as the method using molecular solvent
Table 1 Comparison of reaction solvent (ILs vs molecular solvent) for the preparation of $4-\mathrm{tBuPcH}_{2}$

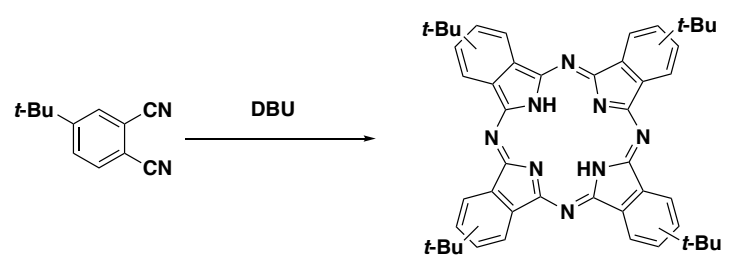

\begin{tabular}{lccc}
\hline Solvent & $\begin{array}{c}\text { Temp./ } \\
{ }^{\mathbf{0}} \mathbf{C}\end{array}$ & $\begin{array}{c}\text { Time / } \\
\mathbf{h}\end{array}$ & Yield / \% \\
\hline$\left[\mathbf{C}_{2-\mathrm{OH}_{2}} \mathbf{i m}\right][\mathbf{B r}]$ & 120 & 6 & 38 \\
\hline EtOH & 78 & 24 & 4.4 \\
\hline
\end{tabular}

[4-tert-butylphthalonitrile $]=0.9 \mathrm{M},[\mathrm{DBU}]=1.0 \mathrm{M}$.

alcohol. ${ }^{19}$ (1) Alkoxide is formed from alcohol by DBU. (2) The alkoxide accelerates the reaction by nucleophilic attack on the carbon of the cyano group of 4-tert-butylphthalonitlile.

The effect of $\mathrm{C}_{2}-\mathrm{H}$ of imidazolium ring was investigated by using $\left[\mathrm{C}_{2-\mathrm{OH}} \mathrm{mim}\right][\mathrm{Br}]$. 4- $\mathrm{BuPcH}_{2}$ was obtained in $38 \%$ yield in $\left[\mathrm{C}_{2-\mathrm{OH}} \mathrm{m}_{2} \mathrm{im}\right][\mathrm{Br}]$ in which the $\mathrm{C}_{2}$ position of imidazolium ring was substituted with a methyl group (Table 2, Entry 1), while 4- $\mathrm{BuPcH}_{2}$ was obtained in $20 \%$ yield in $\left[\mathrm{C}_{2-\mathrm{OH}} \mathrm{mim}\right][\mathrm{Br}]$ with $\mathrm{C}_{2}-\mathrm{H}$. Both reactions are carried out in the presence of stronger base DBU. The acidity of the imidazolium $\mathrm{C}_{2}-\mathrm{H}$ is relatively high $\left(\mathrm{p} K_{\mathrm{a}}=\right.$ $21-23$ ), and its value was roughly intermediate between the acidities of acetone $\left(\mathrm{p} K_{\mathrm{a}}=19.3\right)$ and ethyl acetate $\left(\mathrm{p} K_{\mathrm{a}}\right.$ $=25.6){ }^{20}$ It is well known from the seminal work of Arduengo that deprotonation at the $\mathrm{C}_{2}$ position of the imidazolium salt generates $\mathrm{N}$-heterocyclic carbene. ${ }^{21}$ Therefore, it is reasonable to surmise that the carbene generated by deprotonation of the acidic $\mathrm{C}_{2}-\mathrm{H}$ by $\mathrm{DBU}$ interferes with the phthalocyanine formation.

The influence of cation skeleton was investigated by $\left[\mathrm{C}_{2-\mathrm{OH}} \mathrm{Py}\right][\mathrm{Br}]$. In $\left[\mathrm{C}_{2-\mathrm{OH}} \mathrm{m}_{2} \mathrm{im}\right][\mathrm{Br}]$ with imidazolium skeleton, 4-tBuPcH${ }_{2}$ was obtained in $38 \%$ yield (Table2,

Table 2 The preparations of 4- $\mathrm{BuPcH}_{2}$ in several ILs

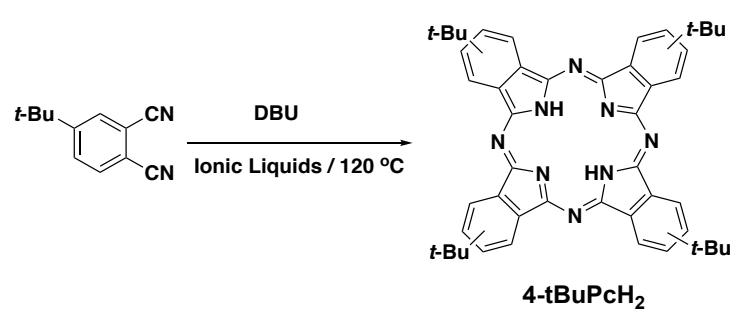

\begin{tabular}{clcc}
\hline Entry & Ionic liquids & Time $/ h$ & Yield $/ \%$ \\
\hline 1 & {$\left[\mathrm{C}_{2-\mathrm{OH}} \mathrm{m}_{2} \mathrm{im}\right][\mathrm{Br}]$} & 6 & 38 \\
2 & {$\left[\mathrm{C}_{4} \mathrm{~m}_{2} \mathrm{im}\right][\mathrm{Br}]$} & 7 & 4 \\
3 & {$\left[\mathrm{C}_{2-\mathrm{OH} m i m}\right][\mathrm{Br}]$} & 6 & 20 \\
4 & {$\left[\mathrm{C}_{2-\mathrm{OH}} \mathrm{Py}\right][\mathrm{Br}]$} & 20 & trace \\
5 & {$\left[\mathrm{C}_{2-\mathrm{OH}} \mathrm{m}_{2} \mathrm{im}\right][\mathrm{Cl}]$} & 6 & 14 \\
6 & {$\left[\mathrm{C}_{2-\mathrm{OH}} \mathrm{im}\right]\left[\mathrm{N}(\mathrm{CN})_{2}\right]$} & 6 & 6 \\
7 & {$\left[\mathrm{C}_{6-\mathrm{OH}} \mathrm{m}_{2} \mathrm{im}\right][\mathrm{Br}]$} & 7 & 18 \\
\hline
\end{tabular}

[4-tert-butylphthalonitrile] $=0.9 \mathrm{M},[\mathrm{DBU}]=1.0 \mathrm{M}$. 
Entry 1). In $\left[\mathrm{C}_{2-\mathrm{OH}} \mathrm{Py}\right][\mathrm{Br}]$ with pyridinium skeleton,only a trace amount of $4-\mathrm{tBuPcH}_{2}$ was generated, and could not be isolated (Table 2, Entry 4). Chauhan and coworkers pointed out the possibility that the pyridinium ILs was decomposed in the presence of DBU in the metallophthalocyanines synthesis using pyridinium ILs. ${ }^{18}$ For the same reason, 4-tBuPcH $\mathrm{H}_{2}$ cannot be generated in $\left[\mathrm{C}_{2-\mathrm{OH}} \mathrm{Py}\right][\mathrm{Br}]$.

The influence of anion species was investigated. 4-tBuPcH ${ }_{2}$ was prepared in three type ILs with different anions, $\left[\mathrm{C}_{2-\mathrm{OH}} \mathrm{m}_{2} \mathrm{im}\right][\mathrm{X}]\left(\mathrm{X}=\mathrm{Br}, \mathrm{Cl}, \mathrm{N}(\mathrm{CN})_{2}\right)$ (Table 2, Entry $1,5,6)$. In $\left[\mathrm{C}_{2-\mathrm{OH}} \mathrm{m}_{2} \mathrm{im}\right][\mathrm{Br}], 4-\mathrm{tBuPcH}_{2}$ was obtained in $38 \%$ yield (Table 2, Entry 1), whereas in $\left[\mathrm{C}_{2-\mathrm{OH}} \mathrm{m}_{2} \mathrm{im}\right][\mathrm{Cl}],\left[\mathrm{C}_{2-\mathrm{OH}} \mathrm{m}_{2} \mathrm{im}\right]\left[\mathrm{N}(\mathrm{CN})_{2}\right], 4-\mathrm{tBuPcH}_{2}$ was obtained in $20 \%, 6 \%$ respectively (Table 2, Entry 5, 6). The Lewis basicity of the anion seems to be influenced the reaction. As mentioned above, the formation of phthalocyanine is accelerated by the nucleophilic attack of alkoxide on the carbon of cyano group. ${ }^{19}$ These results suggested that not only alkoxide but also Lewis base of the anion participates in the reaction. $\mathrm{Br}^{-}$and $\mathrm{Cl}^{-}$has a higher Lewis basicity than that of $\mathrm{N}(\mathrm{CN})_{2}^{-}$. The high basicity of $\mathrm{Br}^{-}$and $\mathrm{Cl}^{-}$can greatly promote the phthalocyanine formation. Although there is little difference in Lewis basicity between $\mathrm{Br}^{-}$and $\mathrm{Cl}^{-}$, the yields of $4-\mathrm{tBuPcH}_{2}$ in these two ILs are very different. The difference in yield can be explained by HSBA (hard and soft acids and bases) principle. The carbon of the cyano group in phthalonitrile was a soft acid, and it shows high affinity for the moderate hard base $\mathrm{Br}^{-}$than hard base $\mathrm{Cl}^{-}$. Thus, it is reasonable surmised that the carbon of the cyano group can be attacked nucleophilically by $\mathrm{Br}^{-}$anion than $\mathrm{Cl}^{-}$anion.

The spacer length between the imidazolium ring and the hydroxy group was investigated. In $\left[\mathrm{C}_{2-\mathrm{OH}} \mathrm{m}_{2} \mathrm{im}\right][\mathrm{Br}]$ with a short spacer (C2), 4-tBuPcH ${ }_{2}$ was obtained in $38 \%$ yield (Table 2, Entry 1), whereas in $\left[\mathrm{C}_{6-\mathrm{OH}} \mathrm{m}_{2} \mathrm{im}\right][\mathrm{Br}]$ with a long spacer (C6), 4-tBuPcH 2 was obtained in $18 \%$ yield (Table 2, Entry 7). As mentioned above, the formation of phthalocyanine is accelerated by alkoxide which generated by deprotonation of hydroxy group, and the stability of the generated alkoxide seems to have influenced the reactivity. It is expected that the alkoxide is stabilized when the negative charge of alkoxide is closer to the positive charge of imidazolium cation. Therefore, $\left[\mathrm{C}_{2-\mathrm{OH}} \mathrm{m}_{2} \mathrm{im}\right][\mathrm{Br}]$ with a short spacer can accelerate the reaction rate than $\left[\mathrm{C}_{6-\mathrm{OH}} \mathrm{m}_{2} \mathrm{im}\right][\mathrm{Br}]$ with a long spacer.

Most effective catalysts for the 4- $\mathrm{BuPcH}_{2}$ preparation,

Table 3 Recycling of $\left[\mathrm{C}_{2}-\mathrm{OHm}{ }_{2} \mathrm{im}\right][\mathrm{Br}]$ in the preparation of $4-\mathrm{tBuPcH}_{2}$

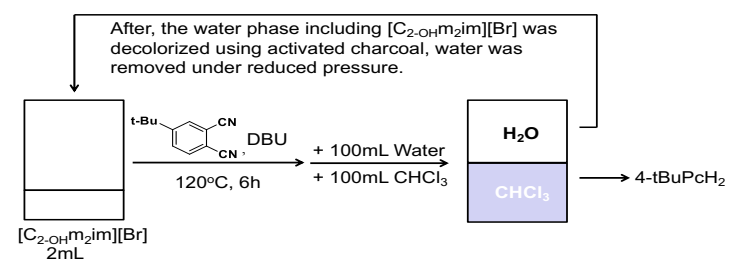

\begin{tabular}{llcc}
\hline Cycle & Ionic liquids & 1 & 2 \\
Yield $/ \%$ & {$\left[\mathrm{C}_{2-\mathrm{OH}} \mathrm{m}_{2} \mathrm{im}\right][\mathrm{Br}]$} & 33 & 32 \\
\hline [4-tert-butylphthalonitrile $]=0.9 \mathrm{M},[\mathrm{DBU}]=1.0 \mathrm{M}$
\end{tabular}

$\left[\mathrm{C}_{2-\mathrm{OH}} \mathrm{m}_{2} \mathrm{im}\right][\mathrm{Br}]$ was reused in second cycle of the reaction, as shown in Table 3. After first cycle of the reaction, $\left[\mathrm{C}_{2-\mathrm{OH}} \mathrm{m}_{2} \mathrm{im}\right][\mathrm{Br}]$ was diluted with water and 4-tBuPcH $\mathrm{H}_{2}$ was extracted with chloroform. The water phase including $\left[\mathrm{C}_{2}-\mathrm{OH}_{2} \mathrm{im}\right][\mathrm{Br}]$ was washed with chloroform, then it was decolorized using activated charcoal. After water was evaporated, it was confirmed by the ${ }^{1} \mathrm{H}$ NMR that $\left[\mathrm{C}_{2-\mathrm{OH}} \mathrm{m}_{2} \mathrm{im}\right][\mathrm{Br}]$ does not contain impurities. 4-tert-butylphthalonitrile and DBU were added to the recovered ILs and the reaction was carried out again. The yields of first and second cycle were almost same as $33 \%$ and $32 \%$, respectively. The use of recycled $\left[\mathrm{C}_{2-\mathrm{OH}} \mathrm{m}_{2} \mathrm{im}\right][\mathrm{Br}]$ did not affect the productivity of phthalocyanine at all.

\section{CONCLUSION}

It was revealed that the optimum ILs structure for the preparation of $4-\mathrm{HuPcH}_{2}$ is $\left[\mathrm{C}_{2-\mathrm{OH}} \mathrm{m}_{2} \mathrm{im}\right][\mathrm{Br}]$. In addition, $\left[\mathrm{C}_{2-\mathrm{OH}} \mathrm{m}_{2} \mathrm{im}\right][\mathrm{Br}]$ could be reused without any loss of its catalytic activity. The utilization of ILs enabled effective and green phthalocyanine synthesis. Further investigation to apply this method to other useful phthalocyanine derivatives are being made in our laboratory.

\section{ACKNOWLEDGEMENTS}

This work was supported by JSPS KAKENHI Grant Numbers 25810109, 26600028, 15K05598, 16K05874 and JST A-STEP Number AS242Z02498M.

\section{REFERERENCES}

[1] A. K. Sarker, G. M. Kang, J. D. Hong, Dyes and Pigments, 92, 1160-1165 (2012).

[2] K. Harbeck, C. Tasaltin, I. Gurol, E. Musluoglu, V. Ahsen, Z. Z. Ozturk, Sens. Actuators, B Chem., 150, 616-624 (2010).

[3] W. Duan, P-C. Lo, L. Duan, W-P. Fong, D. K. P. Ng, Bioorg. Med. Chem., 18, 2672-2677 (2010).

[4] H. S. Nalwa, M. K. Engel, M. Hanack, H. Schultz, Appl. Organomet. Chem., 10, 661-664 (1996).

[5] F. Maeda, K. Hatsusaka, K. Ohta, M. Kimura, J. Mater. Chem., 13, 243-251 (2003).

[6] J. H. Zagal, S. Griveau, J. F. Silva, T. Nyokong, F. Bedioui, Coord. Chem. Rev., 254, 2755-2791 (2010).

[7] "Phthalocyanines-Properties a d Applications", Vol. 1-4, Ed. by C.C. Lenzoff, A. B. P. Lever, VCH, New York, (1989-1996).

[8] T. Welton, Chem. Rev., 99, 2071-2084 (1999).

[9] P. Wasserscheid, W. Keim, Angew. Chem. Int. Ed., 39, 3772-3789 (2000).

[10] S. Kitaoka, K. Nobuoka, Y. Ishikawa, Chem. Commun., 1902-1903 (2004).

[11] S. Kitaoka, K. Nobuoka, Y. Ishikawa, Tetrahedron., 61, 7678-7685 (2005).

[12] S. Kitaoka, K. Nobuoka, R. Hirakawa, K. Ihara, Y. Ishikawa, Chem. Lett., 42, 1397-1399 (2013).

[13] S. Kitaoka, K. Nobuoka, R. Hirakawa, K. Ihara, Y. Ishikawa, $R S C A d v$., 4, 26777-26782 (2014).

[14] P.-C. Lo, Y. Y. Cheng, D. K. P. Ng, Synthesis., 7, 1141-1147 (2005).

[15] N. Safari, P. R. Jamaat, S. A. Shirvan, S. Shoghpour, A. Ebadi, DM. Darvishi, A. Shaabani, J. Porphyrins Phthalocyanines, 9, 256- 261 (2005). 
[16] A. Shaabani, A. H. Rezayan, J. Porphyrins Phthalocyanines, 9, 617-620 (2005).

[17] S. M. S. Chauhan, S. Agarwel, P. Kumari, Syn. Commun., 37, 2917-2925 (2007).

[18] S. M. S. Chauhan, P. Kumari, S. Agarwel, Synthesis, 23, 3713-3727 (2007).

[19] "Handbook of Porphyrin Science with Applications to Chemistry, Physics, Materials Science, Engineering, Biology and Medicine", Vol. 41-44, Ed. by K. M. Kadish, K. M. Smith, R. Guilard, World Scientific, (2016).

[20] T. L. Amyes, S. T. Diver, J. P. Richard, F. M. Rivas, K. Toth, J. Am. Chem. Soc., 126, 4366-4374 (2004).

[21] A. J. Arduengo III, Acc. Chem. Res., 32, 913-921 (1999).

(Received February 6, 2019; Accepted March 18, 2019;

Published Online June 1, 2019) 